IOS Press

\title{
Comparison of different chemical and non-chemical alternatives to Methyl Bromide for strawberry in Huelva (Spain) ${ }^{1}$
}

\author{
J.J. Medina-Mínguez, L. Miranda, P. Domínguez, C. Soria, R.M. Pérez-Jiménez, T. Zea, M. Talavera, \\ L. Velasco, F. Romero, B. De Los Santos and J.M. López-Aranda* \\ IFAPA, Instituto de Investigación y Formación Agraria y Pesquera, Consejería de Agricultura y Pesca, \\ Junta de Andalucía, Sevilla, Spain
}

Received 11 November 2011; accepted 10 December 2011

\begin{abstract}
Spain's Methyl Bromide (MB) Alternatives Project" has been developing/demonstrating alternative fumigants for methyl bromide on strawberry in Huelva since 1997. Here, we describe our research carried out between 2008 and 2010. In all the trials 'Camarosa' was grown under high plastic tunnels between October and the end of May every year. Field trials with the same complete randomized block design and 10-12 treatments were performed annually in two locations of Huelva ("Occifresa"-Moguer and "Cumbres Malvinas"-Palos de la Frontera.). In 2007/08 and 2008/09 the following ten treatments were applied: untreated control; $\mathrm{MB}+$ chloropicrin $(50: 50 \mathrm{w} / \mathrm{w})$; sodium azide; dazomet + 1,3D(dichloropropene); $1,3 \mathrm{D}+$ chloropicrin $(61: 35 \mathrm{w} / \mathrm{w})$; chloropicrin alone; DMDS (dimethyl disulphide) + chloropicrin; methyl iodide + chloropicrin (50:50 w/w); acrolein; and furfural. In 2009/10, non-chemical treatments (biosolarization) were included; in comparison with previous year, four additional treatments were applied: biosolarization with fresh poultry manure $(25,000 \mathrm{~kg} / \mathrm{ha})$, biosolarization with Brassica pellets $(2,000 \mathrm{~kg} / \mathrm{ha})$, sodium tethathiocarbamate and metam sodium shank-applied with Rotary Spader implement. Black root rot complex (Fusarium spp., Cylindrocarpon spp., Rhizoctonia spp., and Pythium spp.) and nematodes Meloidogyne hapla and Pratylenchus penetrans were the main phytosanitary problems related to the soil, and Macrophomina phaseolina was detected occasionally in the first two seasons. However, plant survival, fruit size and yields were optimal in both locations. In 2009/10 at "Occifresa"-Moguer a higher percentage of dead plants was evidenced, and at an earlier stage than the previous growing seasons, mainly caused by Macrophomina phaseolina and Fusarium oxysporum. DMDS + chloropicrin, 1,3D + chloropicrin and chloropicrin alone were as effective as $\mathrm{MB}$ : chloropicrin. Biosolarization with fresh chicken manure $(25,000 \mathrm{~kg} / \mathrm{ha})$ showed higher production than the untreated control.
\end{abstract}

Keywords: Fumigants, fungal diseases, Methyl Bromide phase-out, nematodes, production

\section{Introduction}

Strawberry crops have been the most relevant Methyl Bromide (MB) consumers within Spain [1]. This soil fumigant was definitively phased-out for strawberry in the European Union in 2007. The "Spain's Methyl Bromide Alternatives Project" has developed activities on strawberry in Huelva since 1997/98; in the 1997-2001 period several chemical and non-chemical control highlighted as potential alternatives to MB for coastal Huelva and Mediterranean areas.

\footnotetext{
${ }^{1}$ Paper presented at 28th International Horticulture Congress, IHC 2010, Lisbon, Portugal.

*Corresponding author: J.M. López-Aranda, IFAPA Centro de Churriana, Cortijo de la Cruz s/n, 29140 Churriana, Málaga, Spain. Tel.: +34 951036200; Fax: +34 951036227; E-mail: josem.lopez.aranda@ juntadeandalucia.es.
} 
These were 1,3dichloropropene : chloropicrin $(61: 35 \% \mathrm{w} / \mathrm{w})$, chloropicrin alone, dazomet, and soil solarization combined with metam sodium at low rate [18].

On the other hand, since 2002/03 a series of field trials with chemical and non-chemical alternatives have been conducted in two locations in the coastal area of Huelva, that is a major reference for other Mediterranean strawberry industries abroad: "Occifresa" Farm (Moguer; location 1) and "Cumbres Malvinas" Farm (Palos de la Fra., location 2); both of them in conventional crop system. So far, more than 20 alternative fumigants have been evaluated in this series of experiments, i.e., MB + chloropicrin, 1,3-dichloropropene + chloropicrin (1,3D : chloropicrin), chloropicrin alone, metam sodium, dimethyl disulphide (DMDS), ethanedinitrile, propylene oxide, sodium tetrathiocarbamate, methyl iodide + chloropicrin, essential oils, were shank-applied, or drip-irrigated such as sodium azide, furfural under mulched (VIF LDPE film) pre-formed beds, or incorporated into the soil: dazomet and calcium cyanamide $[16,17]$.

\section{Materials and methods}

During the growing seasons of 2007/08, 2008/09 and 2009/10, field trials with chemical and non-chemical alternatives have been conducted in two locations of Huelva: "Occifresa" Farm (Moguer) (location 1) and "Cumbres Malvinas" Farm (Palos de la Fra.) (location 2). Field trials consisting in the same complete randomized blocks (3 replications, $78 \mathrm{~m}^{2}$ per replication) and 10-12 treatments have been conducted annually.

In 2007/08 and 2008/09 ten treatments were applied under mulched beds with black VIF film (2007/08) and black polyethylene film (2008/09): untreated control; MB + chloropicrin (50:50w/w); sodium azide; dazomet + dichloropropene; 1,3D dichloropropene + chloropicrin $(61: 35 \mathrm{w} / \mathrm{w})$; chloropicrin alone; DMDS (dimethyl disulphide) + chloropicrin; methyl iodide + chloropicrin (50:50 w/w); acrolein; and, furfural (Table 1). In 2009/10, twelve treatments were used, under mulched beds with black polyethylene film, including biosolarization with fresh chicken manure $(25,000 \mathrm{~kg} / \mathrm{ha})$; biosolarization with Brassica pellets (Italia of Cerealtoscana Group) $(2,000 \mathrm{~kg} / \mathrm{ha})$; and, sodium tethathiocarbamate and metam sodium shank-applied with modern Rotary Spader implement (Table 2).

Chemical fumigants were applied every year (from mid-August to mid-September) and superimposed on the same parcels and replications; except in Palos de la Fra. (location 2) (2009/10), where after seven growing seasons, we were required to move our field trial into a new parcel within the same farm shank-fumigated with $1,3 \mathrm{D}+$ chloropicrin since 2007/08. In 2009/10, non-chemical treatments (biosolarization) were applied during the

Table 1

2007/08 \& 2008/09. Treatments applied to soils in fields of 'Camarosa' grown at two locations in Huelva (Spain)

\begin{tabular}{|c|c|c|c|}
\hline \multirow[t]{2}{*}{ Treatment } & \multicolumn{2}{|c|}{ Rate (kg/ha of treated area) } & \multirow[t]{2}{*}{ Method of application } \\
\hline & $2007 / 08^{1}$ & $2008 / 09^{2}$ & \\
\hline Control & Untreated & Untreated & - \\
\hline MB : chloropicrin $(50-50)$ (Bromofifty $\left.{ }^{\circledR}\right)$ & 400 & 400 & Shank, 2 chisels in bed \\
\hline Sodium azide $\left(\mathrm{SEP}-100^{\circledR}\right)$ & 120 a.i. ${ }^{3}$ & 160 a.i. ${ }^{3}$ & Pre-plant drip irrigation \\
\hline Dazomet : 1,3-D & $80+400$ & $80+400$ & Pre-plant drip irrigation \\
\hline 1,3-D : chloropicrin (Telopic ${ }^{\circledR}$ ) & 300 & 400 & Shank, 2 chisels in bed \\
\hline Chloropicrin alone (Tripicrin ${ }^{\circledR}$ ) & 300 & 400 & Shank, 2 chisels in bed \\
\hline DMDS : chloropicrin & $300+100$ & $300+130$ & Shank, 2 chisels in bed \\
\hline Methyl iodide : chloropicrin (50-50) $\left(\right.$ Midas $\left.^{\circledR}\right)$ & 300 & 400 & Shank, 2 chisels in bed \\
\hline Acrolein $\left(\right.$ Magnacide ${ }^{\circledR}$ ) & 180 & 240 & Pre-plant drip irrigation \\
\hline Furfural (Multiguard Protect ${ }^{\circledR}$ ) & $44 \mathrm{ml} / \mathrm{m}^{2}$ a.i. ${ }^{3}+2.8 \mathrm{ml} / \mathrm{m}^{2}$ & $60 \mathrm{ml} / \mathrm{m}^{2}$ a.i. $^{3}$ & $\begin{array}{l}\text { Pre-plant drip } \\
\text { irrigation + monthly drip } \\
\text { irrigation during six } \\
\text { months in } 2007 / 08\end{array}$ \\
\hline
\end{tabular}

\footnotetext{
${ }^{1}$ Black VIF film; ${ }^{2}$ Black polyethylene film; ${ }^{3}$ a.i. = active ingredient.
} 
Table 2

2009/10. Treatments applied to soils in fields of 'Camarosa' grown at two locations in Huelva (Spain)

\begin{tabular}{lcc}
\hline Treatment & Rate $(\mathrm{kg} /$ ha treated area) & Method of application \\
\hline Control & Untreated & - \\
MB : chloropicrin $(50-50)\left(\right.$ Bromofifty $\left.^{\circledR}\right)$ & 400 & Shank, 2 chisels in bed \\
Biosolarization with fresh chicken manure & 25,000 & Pre-plant broadcast \\
Dazomet : 1,3-D & $80+400$ & Pre-plant drip irrigation \\
Biosolarization with Brassica pellets (Biofence $\left.{ }^{\circledR}\right)$ & 2,000 & \\
1,3-D : chloropicrin (61-35) $\left(\right.$ Telopic $\left.^{\circledR}\right)$ & 400 & Shank, 2 chisels in bed \\
Chloropicrin alone (Tripicrin $\left.{ }^{\circledR}\right)$ & 400 & Shank, 2 chisels in bed \\
DMDS : chloropicrin & $400+130$ & Shank, 2 chisels in bed \\
Methyl iodide : chloropicrin $(98-2)\left(\right.$ Gold $\left.^{\circledR}\right)$ & 110 & Pre-plant drip irrigation \\
Sodium tetrathiocarbamate $\left(\right.$ Enzone $\left.^{\circledR}\right)$ & $300+501,2$ & Rotary spader + monthly drip \\
& & irrigation during six \\
Methyl iodide : chloropicrin $(98-2)\left(\right.$ Gold $\left.^{\circledR}\right)$ & 150 & months \\
Metam sodium $\left(\right.$ Laysol $\left.^{\circledR}\right)$ & 1250 & Pre-plant drip irrigation \\
\hline
\end{tabular}

${ }^{1}$ Black VIF film; ${ }^{2}$ In drip irrigation six application of $50 \mathrm{kh} / \mathrm{ha}$.

second week of July and soil solarization was conducted from mid-July to mid-August. 'Camarosa' plants were planting each season at mid-October and were grown, following IPM practices under high plastic tunnels until late May every year.

Controls of the sanitary status of plants were done by sampling fifty plants per location before planting. To detect fungal infections, crowns and 5-cm-long root-segments were surface disinfected, plated on potato dextrose agar and cultivated at $25^{\circ} \mathrm{C}$ for seven days in the dark. To detect nematode infections, plant roots and leaves were cut into small pieces and processed by the sugar centrifugation method [23]. Soil samples from each replication were also evaluated for fungal presence before (early-July) and after (October) treatments.

Ten randomly selected plants from each replication were observed throughout the complete growing season; plant diameter (plant vigour) was determined by taking measurements across the above ground foliage. The incidence of crown and root fungal diseases and nematodes in the plants was assessed at the end of each season (early-May) on the same plants selected for plant vigour. Five plants were used to detect soil-borne fungi and five plants to detect nematodes. Additionally, samples of symptomatic plants (in particular collapsed, wilt, or very small plants) were taken. For plant fungi isolation and determination methods were according to the literature [10, 11, 20, 28]. Regarding the nematodes, the Gall Index was recorded in a 0-4 rating scale (being value 0 absence of symptoms and 4 all roots attacked) [4]. Roots from the five selected plants from each replication were joined in one single sample of $10 \mathrm{~g}$ and sedentary forms of $M$. hapla and endoparasitics forms of $P$. penetrans were extracted and quantified by the sugar centrifugation method [23].

Plant survival, early (end-March) and total yield (end-May) and fruit size were recorded throughout the production season (mid-January to end-May) at both locations.

Data were submitted to analysis of variance and treatment means were compared with Fischer's protected least significant difference test at the 5\% significance level (Statistix v. 8.0, Tallahassee, Florida, USA).

\section{Results}

In 2007/08, the commercial yields of chloropicrin alone, DMDS + chloropicrin, 1,3D + chloropicrin and dazomet + dichloropropene were higher than the standard MB + chloropicrin $(50: 50)$; in general, the agronomical traits and yields were optimal in both locations (Table 3). On the other hand, MB + chloropicrin (50:50), sodium azide, dazomet + dichloropropene, DMDS + chloropicrin and methyl iodide + chloropicrin (50:50), all reduced the initial fungal population significantly (data not shown). High isolation frequencies of Cylindrocarpon spp. in roots 
Table 3

2007/08. Total commercial yield in g/plant and relative yield in different pre-plant fumigation treatments in fields of 'Camarosa' grown at two locations in Huelva (Spain)

\begin{tabular}{|c|c|c|c|c|c|c|}
\hline \multirow[t]{2}{*}{ Treatments } & \multicolumn{2}{|c|}{ Loc. 1: Occifresa } & \multicolumn{2}{|c|}{ Loc. 2: C. Malvinas } & \multicolumn{2}{|c|}{ Two loc. average } \\
\hline & Total yield $^{1}$ & Relative yield $^{2}$ & Total yield $^{1}$ & Relative yield $^{2}$ & Total yield $^{1}$ & Relative yield $^{2}$ \\
\hline Control & $865 \mathrm{~d}$ & 78.2 & $777 \mathrm{f}$ & 76.9 & $821 \mathrm{~g}$ & 77.6 \\
\hline MB : chloropicrin $(50-50)$ & $1106 a b$ & 100 & $1010 \mathrm{cde}$ & 100 & $1058 \mathrm{bcd}$ & 100 \\
\hline Sodium azide & $1007 \mathrm{bc}$ & 91.0 & $968 \mathrm{e}$ & 95.8 & $986 \mathrm{e}$ & 93.2 \\
\hline Dazomet : 1,3-D & $1113 \mathrm{ab}$ & 100.6 & 1030 cde & 102.0 & $1072 \mathrm{bc}$ & 101.3 \\
\hline 1,3-D : chloropicrin & $1045 a b c$ & 94.5 & $1101 \mathrm{ab}$ & 109.0 & $1073 \mathrm{bc}$ & 101.4 \\
\hline Chloropicrin alone & $1164 \mathrm{a}$ & 105.0 & $1124 \mathrm{a}$ & 111.3 & $1144 \mathrm{a}$ & 108.1 \\
\hline DMDS : chloropicrin & $1091 \mathrm{abc}$ & 98.6 & $1098 \mathrm{ab}$ & 108.7 & $1095 \mathrm{ab}$ & 103.5 \\
\hline Methyl iodide : chloropicrin $(50-50)$ & $1045 \mathrm{abc}$ & 94.5 & 1002 cde & 99.2 & 1023 cde & 96.7 \\
\hline Acrolein & $1005 \mathrm{bc}$ & 90.9 & $993 \mathrm{e}$ & 98.3 & 999 de & 94.4 \\
\hline Furfural & $970 \mathrm{~cd}$ & 87.7 & $841 \mathrm{f}$ & 83.3 & $906 \mathrm{f}$ & 85.6 \\
\hline
\end{tabular}

${ }^{1}$ Cumulated up to May 22nd, 2008; ${ }^{2}$ Relative yield in relation to MB standard treatment MB : CP $(50-50)=100 \% ; P \leq 0.05$. Means followed by the same letter in each column were not significantly different $(P \leq 0.5)$ by the LSD test.

and Fusarium spp. in crowns, low isolation frequencies of Rhizoctonia spp., and increasing isolation frequencies of species of Pythium spp. were detected in both locations at the end of the growing season (black root rot complex). Macrophomina phaseolina was detected occasionally in plots of untreated control and furfural in location 1 ("Occifresa"). Nematode Pratylenchus penetrans was detected in samples from "Occifresa" (location 1) and Meloidogyne hapla was observed in samples from "Cumbres Malvinas" (location 2) at the end of the cultivation period (Table 4). In the case of $P$. penetrans sodium azide, chloropicrin alone, acrolein and furfural did not reduced nematode populations at the end of the season compared to the untreated control. In addition, dazomet + dichloropropene, 1,3D + chloropicrin, DMDS + chloropicrin and methyl iodide + chloropicrin showed the same capacity of reduced the nematode population that $\mathrm{MB}+$ chloropicrin. In the case of M. hapla the gall index (severity index) as well as the number of sedentary forms recovered from roots at the end of the season, were higher in sodium azide, acrolein and furfural treatments not reducing the nematode populations in comparison with the untreated control. The remaining treatments were as effective as MB + chloropicrin (Table 4).

In 2008/09, the commercial yields of DMDS + chloropicrin, 1,3D + chloropicrin, methyl iodide + chloropicrin $(50: 50)$, chloropicrin alone and dazomet + dichloropropene were higher or equal than the standard MB + chloropicrin (50:50); also, the agronomical traits and yields (Table 5) were optimal in both locations. Most of the treatments reduced significantly initial fungal populations (data not shown); however, some treatments were less effective (location 1 "Occifresa": untreated control and furfural, and location 2 "Cumbres Malvinas": untreated control and 1,3D + chloropicrin). Fusarium spp., Cylindrocarpon spp. and Rhizoctonia spp., were frequently isolated from location 1 ("Occifresa") and 2 ("Cumbres Malvinas"). Presence of Pythium was increased in location 2 and not detected in location 1 at the end of the growing season. Macrophomina phaseolina and Phytophthora cactorum were isolated in both locations. Once again, nematode Pratylenchus penetrans was detected in samples from "Occifresa" (location 1) and Meloidogyne hapla from "Cumbres Malvinas" (location 2) at the end of the cultivation period (Table 6). MB + chloropicrin $(50: 50)$ and methyl iodide + chloropicrin $(50: 50)$ were the most effective to control Pratylenchus penetrans populations, whilst small differences were observed for the control of Meloidogyne hapla (Table 6).

In 2009/10, our results have been influenced by the change of experimental parcels in "Cumbres Malvinas" (location 2). In "Occifresa" (location 1), the commercial yields of DMDS + chloropicrin, 1,3D + chloropicrin and chloropicrin alone were equal than with the standard $\mathrm{MB}+$ chloropicrin $(50: 50)$, not only in g/plant but also in $\mathrm{kg} / \mathrm{ha}$. Dazomet + dichloropropene and biosolarization with fresh chicken manure $(25,000 \mathrm{~kg} / \mathrm{ha})$ were slightly less productive than the standard $\mathrm{MB}+$ chloropicrin without significant differences among treatments (Table 7). In location 1, using the same fumigant treatments repeated growing season after growing season in the same replications, differences in agronomic traits and dead plant percentage observed during the second part of the 
Table 4

2007/08. Nematode populations in different pre-plant fumigation treatments at the end of the growing season in fields of 'Camarosa' grown at two locations in Huelva (Spain)

\begin{tabular}{|c|c|c|c|c|}
\hline \multirow[t]{2}{*}{ Treatments } & \multirow{2}{*}{$\begin{array}{c}\text { Loc. 1: Occifresa: } \\
\text { Pratylenchus penetrans } \\
\text { Individuals/g roots }\end{array}$} & \multicolumn{3}{|c|}{$\begin{array}{l}\text { Loc. 2: C. Malvinas } \\
\text { Meloidogyne hapla }\end{array}$} \\
\hline & & $\begin{array}{c}\text { Gall Index: } \\
\text { Severity Index }{ }^{1}\end{array}$ & $\begin{array}{l}\mathrm{N}^{\circ} \text { eggs }+ \\
\mathrm{J}_{2} / \mathrm{g} \text { roots }\end{array}$ & $\begin{array}{c}\text { Females/g } \\
\text { roots }\end{array}$ \\
\hline Control & $175.7 \mathrm{~d}$ & $3.3 \mathrm{c}$ & $13390.0 \mathrm{~d}$ & $101.0 \mathrm{c}$ \\
\hline MB : chloropicrin $(50-50)$ & $23.0 \mathrm{ab}$ & $0.6 \mathrm{ab}$ & $32.0 \mathrm{ab}$ & $6.0 \mathrm{ab}$ \\
\hline Sodium azide & $102.5 \mathrm{~cd}$ & $2.3 \mathrm{bc}$ & $852.5 \mathrm{abcd}$ & $60.0 \mathrm{bc}$ \\
\hline Dazomet : 1,3-D & $39.5 \mathrm{abc}$ & $0.2 \mathrm{a}$ & $33.5 \mathrm{ab}$ & $9.8 \mathrm{ab}$ \\
\hline 1,3-D : chloropicrin & $33.3 \mathrm{ab}$ & $0.2 \mathrm{a}$ & $9.5 \mathrm{a}$ & $0.1 \mathrm{a}$ \\
\hline Chloropicrin alone & $139.5 \mathrm{~d}$ & $0.6 \mathrm{ab}$ & $265.0 \mathrm{abc}$ & $53.0 \mathrm{bc}$ \\
\hline DMDS : chloropicrin & $11.8 \mathrm{a}$ & $0.5 \mathrm{a}$ & $211.5 \mathrm{abc}$ & $10.9 \mathrm{ab}$ \\
\hline Methyl iodide : chloropicrin (50-50) & $12.5 \mathrm{a}$ & $0.2 \mathrm{a}$ & $4.7 \mathrm{a}$ & $0.5 \mathrm{a}$ \\
\hline Acrolein & $85.5 \mathrm{bcd}$ & $1.9 \mathrm{abc}$ & $5354.0 \mathrm{~cd}$ & $55.0 \mathrm{bc}$ \\
\hline Furfural & $75.0 \mathrm{bcd}$ & $2.4 \mathrm{bc}$ & $2560.3 \mathrm{bcd}$ & $92.0 \mathrm{bc}$ \\
\hline
\end{tabular}

Means followed by the same letter in each column not significantly different $(P \leq 0.5)$ by the LSD test. Transformation $\log (1+\mathrm{x}) .{ }^{1}$ Severity Index Scale: 0 (No symptoms) to 4 (all roots attacked).

Table 5

2008/09. Total commercial yield in g/plant and relative yield in different pre-plant fumigation treatments in fields of 'Camarosa' grown at two locations in Huelva (Spain)

\begin{tabular}{|c|c|c|c|c|c|c|}
\hline \multirow[t]{2}{*}{ Treatments } & \multicolumn{2}{|c|}{ Loc. 1: Occifresa } & \multicolumn{2}{|c|}{ Loc. 2: C. Malvinas } & \multicolumn{2}{|c|}{ Two loc. average } \\
\hline & Total yield $^{1}$ & Relative yield $^{2}$ & Total yield $^{1}$ & Relative yield $^{2}$ & Total yield $^{1}$ & Relative yield $^{2}$ \\
\hline Control & $855 \mathrm{~d}$ & $81.5 \mathrm{~d}$ & $742 \mathrm{~b}$ & $68.9 \mathrm{~b}$ & $799 \mathrm{~d}$ & $75.1 \mathrm{~d}$ \\
\hline MB : chloropicrin (50-50) & $1050 \mathrm{ab}$ & $100.0 \mathrm{ab}$ & $1078 \mathrm{a}$ & $100.0 \mathrm{a}$ & $1064 \mathrm{ab}$ & $100.0 \mathrm{ab}$ \\
\hline Sodium azide & $1024 \mathrm{ab}$ & $97.5 \mathrm{ab}$ & $1015 \mathrm{a}$ & $94.2 \mathrm{a}$ & $1020 \mathrm{abc}$ & $95.8 \mathrm{abc}$ \\
\hline Dazomet : 1,3-D & 1116 a & $106.3 \mathrm{a}$ & $1004 \mathrm{a}$ & $93.2 \mathrm{a}$ & $1060 \mathrm{ab}$ & $99.6 \mathrm{ab}$ \\
\hline 1,3-D : chloropicrin & $1047 \mathrm{ab}$ & $99.7 \mathrm{ab}$ & $1110 \mathrm{a}$ & $102.9 \mathrm{a}$ & $1078 \mathrm{a}$ & $101.3 \mathrm{a}$ \\
\hline Chloropicrin alone & $1025 \mathrm{ab}$ & $97.6 \mathrm{ab}$ & $1116 \mathrm{a}$ & $103.5 \mathrm{a}$ & $1070 \mathrm{ab}$ & $100.6 \mathrm{ab}$ \\
\hline DMDS : chloropicrin & $1068 \mathrm{ab}$ & $101.8 \mathrm{ab}$ & $1119 \mathrm{a}$ & $103.8 \mathrm{a}$ & $1094 \mathrm{a}$ & $102.8 \mathrm{a}$ \\
\hline Methyl iodide : chloropicrin (50-50) & $1067 \mathrm{ab}$ & $101.6 \mathrm{ab}$ & $1076 \mathrm{a}$ & $99.8 \mathrm{a}$ & $1072 \mathrm{ab}$ & $100.7 \mathrm{ab}$ \\
\hline Acrolein & $971 \mathrm{bc}$ & $92.5 \mathrm{ab}$ & $1015 \mathrm{a}$ & $94.2 \mathrm{a}$ & $993 \mathrm{bc}$ & $93.4 \mathrm{bc}$ \\
\hline Furfural & $867 \mathrm{~d}$ & $82.6 \mathrm{~d}$ & $831 \mathrm{~b}$ & $77.1 \mathrm{~b}$ & $849 \mathrm{~d}$ & $79.8 \mathrm{~d}$ \\
\hline
\end{tabular}

${ }^{1}$ Cumulated up to May 23rd, 2009; ${ }^{2}$ Relative yield in relation to MB standard treatment MB : CP $(50-50)=100 \%$. Means followed by the same letter in each column were not significantly different $(P \leq 0.5)$ by the LSD test.

growing season have been enormous. However, small significant differences have been observed among treatments in location 2; as explained above this was because of relocation of the experimental parcels in 2009/10 (data not shown).

During this growing season (2009/10), Meloidogyne hapla in "Cumbres Malvinas" farm (location 2) disappeared. However, the concentration of Pratylenchus penetrans observed in "Occifresa" (location 1) has been much higher than in the previous growing seasons (due to the mild temperatures of fall/winter 2009/10). MB + chloropicrin $(50: 50)$ was the most effective to control Pratylenchus penetrans populations, followed by $1,3 \mathrm{D}+$ chloropicrin, DMDS + chloropicrin and methyl iodide + chloropicrin $(98: 2)(150 \mathrm{~kg} /$ treated ha)., and in the next level of efficacy were metam sodium, dazomet + dichloropropene and biosolarization with fresh chicken manure $(25,000 \mathrm{~kg} / \mathrm{ha})$ (Table 8). 
Table 6

2008/09. Nematode populations in different pre-plant fumigation treatments at the end of the growing season in fields of 'Camarosa' grown at two locations in Huelva (Spain)

\begin{tabular}{|c|c|c|c|c|}
\hline \multirow[t]{2}{*}{ Treatments } & \multirow{2}{*}{$\begin{array}{c}\text { Loc. 1: Occifresa } \\
\text { Pratylenchus penetrans } \\
\text { Individuals/g roots }\end{array}$} & \multicolumn{3}{|c|}{$\begin{array}{l}\text { Loc. 2: C. Malvinas } \\
\text { Meloidogyne hapla }\end{array}$} \\
\hline & & $\begin{array}{c}\text { Gall Index: } \\
\text { Severity Index }{ }^{1}\end{array}$ & $\begin{array}{l}\mathrm{N}^{\circ} \text { eggs }+ \\
\mathrm{J}_{2} / \mathrm{g} \text { roots }\end{array}$ & $\begin{array}{c}\text { Females/g } \\
\text { roots }\end{array}$ \\
\hline Control & $197.5 \mathrm{~cd}$ & $1.3 \mathrm{ab}$ & $2,421.7 \mathrm{~cd}$ & $35.8 \mathrm{~b}$ \\
\hline MB : chloropicrin $(50-50)$ & $9.4 \mathrm{a}$ & $0.1 \mathrm{a}$ & $24.8 \mathrm{a}$ & $6.8 \mathrm{ab}$ \\
\hline Sodium azide & $162.8 \mathrm{~cd}$ & $2.1 \mathrm{~b}$ & $3,199.0 \mathrm{~d}$ & $48.6 \mathrm{~b}$ \\
\hline Dazomet: $1,3-\mathrm{D}$ & $82.0 \mathrm{c}$ & $1.0 \mathrm{ab}$ & $631.0 \mathrm{c}$ & $19.9 \mathrm{ab}$ \\
\hline 1,3-D : chloropicrin & $45.8 \mathrm{bc}$ & $0.0 \mathrm{a}$ & $91.7 \mathrm{ab}$ & $0.4 \mathrm{a}$ \\
\hline Chloropicrin alone & $148.8 \mathrm{~cd}$ & $1.3 \mathrm{ab}$ & $2,574.1 \mathrm{~cd}$ & $35.5 \mathrm{ab}$ \\
\hline DMDS : chloropicrin & $97.1 \mathrm{c}$ & $0.4 \mathrm{ab}$ & $186.5 \mathrm{bc}$ & $2.5 \mathrm{ab}$ \\
\hline Methyl iodide : chloropicrin (50-50) & $11.1 \mathrm{ab}$ & $0.1 \mathrm{a}$ & $17.0 \mathrm{a}$ & $0.7 \mathrm{a}$ \\
\hline Acrolein & $192.3 \mathrm{~cd}$ & $1.7 \mathrm{~b}$ & $2,786.7 \mathrm{~cd}$ & $45.9 \mathrm{~b}$ \\
\hline Furfural & $150.3 \mathrm{~cd}$ & $0.7 \mathrm{ab}$ & $2,540.7 \mathrm{~cd}$ & $50.8 \mathrm{~b}$ \\
\hline
\end{tabular}

Means followed by the same letter in each column were not significantly different $(P \leq 0.05)$ by the LSD test. Transformation $\log (1+\mathrm{x}) .{ }^{1}$ Severity Index Scale: 0 (No symptoms) to 4 (all roots attacked).

Table 7

2009/10. "Occifresa" (location 1). Total commercial yield in g/plant and relative yield in diferent pre-plant fumigation treatments in field of 'Camarosa' grown in Huelva (Spain)

\begin{tabular}{|c|c|c|c|c|}
\hline Treatments & Total yield $^{3} \mathrm{~g} /$ plant & Relative yield $^{4}$ & Total yield ${ }^{3} \mathrm{~kg} / \mathrm{ha}$ & Relative yield $^{4}$ \\
\hline Control & $592 \mathrm{f}$ & $67.4 \mathrm{f}$ & $36846 \mathrm{~g}$ & $62.5 \mathrm{~g}$ \\
\hline MB : chloropicrin $(50-50)$ & $878 \mathrm{ab}$ & $100.0 \mathrm{ab}$ & $58966 \mathrm{abc}$ & $100.0 \mathrm{abc}$ \\
\hline Biosolarization wirh fresh chicken manure & $835 \mathrm{bc}$ & $95.1 \mathrm{bc}$ & $54904 \mathrm{~cd}$ & $93.1 \mathrm{~cd}$ \\
\hline Dazomet : 1,3-D & $867 \mathrm{~b}$ & $98.7 \mathrm{~b}$ & $56314 \mathrm{bc}$ & $95.5 \mathrm{bc}$ \\
\hline Biosolarization Brassica pellets & 624 ef & $71.1 \mathrm{ef}$ & $38931 \mathrm{~g}$ & $66.0 \mathrm{~g}$ \\
\hline 1,3-D : chloropicrin & $928 \mathrm{ab}$ & $105.7 \mathrm{ab}$ & $62461 \mathrm{ab}$ & $105.9 \mathrm{ab}$ \\
\hline Chloropicrin alone & $926 \mathrm{ab}$ & $105.5 \mathrm{ab}$ & $62129 a b$ & $105.4 \mathrm{ab}$ \\
\hline DMDS : chloropicrin & 978 a & $111.4 \mathrm{a}$ & $65415 \mathrm{a}$ & $110.9 \mathrm{a}$ \\
\hline Methyl iodide : chloropicrin $(98-2)^{1}$ & $759 \mathrm{~cd}$ & $86.4 \mathrm{~cd}$ & 48145 de & $81.6 \mathrm{de}$ \\
\hline Sodium tetrathiocarbamate & $605 \mathrm{f}$ & $68.9 \mathrm{f}$ & $37855 \mathrm{~g}$ & $64.2 \mathrm{~g}$ \\
\hline Methyl iodide : chloropicrin $(98-2)^{2}$ & 722 de & 82.2 de & 46869 ef & $79.5 \mathrm{ef}$ \\
\hline Metam sodium & 680 def & $77.4 \mathrm{def}$ & $41087 \mathrm{fg}$ & $69.7 \mathrm{fg}$ \\
\hline
\end{tabular}

${ }^{1} 110 \mathrm{~kg} /$ treated ha; ${ }^{2} 150 \mathrm{~kg} /$ treated ha; ${ }^{3}$ Cumulated up to May $25 \mathrm{rd}, 2010 ;{ }^{4}$ Relative yield in relation to MB standard treatment MB : CP $(50-50)=100 \%$; Means followed by the same letter in each column were not significantly different $(0.5 \leq P)$ by the LSD test.

In location 2 ("Cumbres Malvinas"), isolation frequencies of soil borne fungi and the percentage of dead plants at the end of the growing season were very small (data not shown). However, in location 1 ("Occifresa") the percentage of dead plants during the second part of the growing season (April/May, 2010) was very high and occurred at a much earlier stage than in the previous growing seasons, with significant differences among treatments (Table 9). In these final die-back counts Macrophomina phaseolina and Fusarium oxysporum were identified mainly; also Rhizoctonia spp. and Phytophthora cactorum were detected. 
Table 8

2009/10. "Occifresa" (location 1). Nematode P. penetrans populations in different fumigant treatments at the end of the growing season in field of 'Camarosa' grown in Huelva (Spain)

\begin{tabular}{lc}
\hline Treatments & Individuals/g of roots \\
\hline Control & $993 \mathrm{~d}$ \\
MB : chloropicrin (50-50) & $66 \mathrm{a}$ \\
Biosolarization with fresh chicken manure & $443 \mathrm{bc}$ \\
Dazomet : 1,3-D & $396 \mathrm{bc}$ \\
Biosolarization with Brassica pellets & $533 \mathrm{bcd}$ \\
1,3-D : chloropicrin & $309 \mathrm{~b}$ \\
Chloropicrin alone & $727 \mathrm{~cd}$ \\
DMDS : chloropicrin & $313 \mathrm{~b}$ \\
Methyl iodide : chloropicrin $(98-2)^{1}$ & $505 \mathrm{bcd}$ \\
Sodium tetrathiocarbamate & $649 \mathrm{bcd}$ \\
Methyl iodide : chloropicrin $(98-2)^{2}$ & $320 \mathrm{~b}$ \\
Metam sodium & $350 \mathrm{bc}$ \\
\hline
\end{tabular}

${ }^{1} 110 \mathrm{~kg} /$ treated ha; ${ }^{2} 150 \mathrm{~kg} /$ treated ha; Means followed by the same letter in each column were not significantly different $(P \leq 0.05)$ by the HSD Tukey test. Transformation $\log (1+\mathrm{x})$.

Table 9

2009/2010. "Occifresa" (location 1). Plant diameter $(\mathrm{cm})$ and \% dead plants in different fumigant treatments at the end of the growing season in field of 'Camarosa' grown in Huelva (Spain)

\begin{tabular}{|c|c|c|c|c|c|}
\hline \multirow[t]{2}{*}{ Treatments } & \multicolumn{5}{|c|}{$\%$ Dead plants during the second part of the growing season } \\
\hline & Plant diameter $(\mathrm{cm})$ & April, 6, 2010 & April, 20, 2010 & May, 4, 2010 & May, 21, 2010 \\
\hline Control & $30.5 \mathrm{f}$ & $0.93 \mathrm{abc}$ & $5.83 \mathrm{ab}$ & $21.01 \mathrm{ab}$ & $41.80 \mathrm{ab}$ \\
\hline MB : chloropicrin (50-50) & $38.7 \mathrm{a}$ & $0.00 \mathrm{~d}$ & $0.27 \mathrm{~cd}$ & $0.60 \mathrm{e}$ & $3.78 \mathrm{e}$ \\
\hline Biosolarization chicken manure & $38.4 \mathrm{a}$ & $0.40 \mathrm{abcd}$ & $0.93 \mathrm{~cd}$ & $6.08 \mathrm{~d}$ & $16.25 \mathrm{~cd}$ \\
\hline Dazomet : $1,3-\mathrm{D}$ & $36.0 \mathrm{abcd}$ & $0.53 \mathrm{abcd}$ & $2.65 \mathrm{bc}$ & $9.81 \mathrm{~cd}$ & $24.78 \mathrm{bc}$ \\
\hline Biosolarization Brassica pellets & $31.0 \mathrm{ef}$ & $0.72 \mathrm{abc}$ & $5.63 \mathrm{ab}$ & $26.85 \mathrm{a}$ & $49.89 \mathrm{a}$ \\
\hline 1,3-D : chloropicrin & $37.8 \mathrm{ab}$ & $0.13 \mathrm{bcd}$ & $0.00 \mathrm{~d}$ & $0.20 \mathrm{e}$ & $1.53 \mathrm{e}$ \\
\hline Chloropicrin alone & $37.3 \mathrm{abc}$ & $0.07 \mathrm{~cd}$ & $0.07 \mathrm{~d}$ & $0.86 \mathrm{e}$ & $6.67 \mathrm{de}$ \\
\hline DMDS : chloropicrin & $36.2 \mathrm{abcd}$ & $0.13 \mathrm{bcd}$ & $0.27 \mathrm{~cd}$ & $0.66 \mathrm{e}$ & $3.80 \mathrm{e}$ \\
\hline Methyl iodide : chloropicrin $(98-2)^{1}$ & $32.9 \mathrm{def}$ & $1.47 \mathrm{ab}$ & $4.54 \mathrm{ab}$ & $16.08 \mathrm{abc}$ & $34.77 \mathrm{ab}$ \\
\hline Sodium tetrathiocarbamate & $31.4 \mathrm{ef}$ & $0.61 \mathrm{abcd}$ & $4.65 \mathrm{ab}$ & $18.52 \mathrm{abc}$ & $38.78 \mathrm{ab}$ \\
\hline Methyl iodide : chloropicrin $(98-2)^{2}$ & 34.4 bcde & $0.67 \mathrm{abcd}$ & $2.34 \mathrm{bc}$ & $10.43 \mathrm{bcd}$ & $25.20 \mathrm{bc}$ \\
\hline Metam sodium & 33.7 cdef & $1.54 \mathrm{a}$ & $9.52 \mathrm{a}$ & $27.13 \mathrm{a}$ & $51.5 \mathrm{a}$ \\
\hline
\end{tabular}

${ }^{1} 110 \mathrm{~kg} /$ treated ha; ${ }^{2} 150 \mathrm{~kg} /$ treated ha; Means followed by the same letter in each column were not significantly different $(P \leq 0.05)$ by the LSD test. Transformation arcsin $(\operatorname{sqrt}(\mathrm{X} / 100))$ for \% died plants. May, 21, 10: final die-back counts.

\section{Discussion}

Strawberry production in Spain has been exclusively relied upon the use of methyl bromide (MB) alone or in combination with chloropicrin as preplant soil fumigation treatments for control of soilborne diseases, nematodes, and weeds $[6,8]$ until its phase out as a result of the Montreal Protocol on substances that deplete atmospheric ozone $[2,29]$. In order to look for viable alternatives, research on MB has been intensive throughout the world in the last 15 years $[1,8,13-17,21,24,25]$. 
In this work, $1,3 \mathrm{D}+$ chloropicrin, DMDS + chloropicrin, and chloropicrin alone have outstanding. The effect $1,3 \mathrm{D}+$ chloropicrin has been widely studied throughout the world for controlling fungal disease and nematodes, and in some cases the need of incorporate herbicides along with this alternative to enhance activity against weeds has been pointed [22]. DMDS alone has fungicidal and nematicidal properties. The application of DMDS reduced populations of Pythium ultimum and Fusarium oxysporum [9]. However, other research carried out in strawberry nurseries in Spain has shown inconsistent results in controlling soilborne diseases [5].

The effect of the combination of DMDS + chloropicrin has been previously study and resulted in higher early and total strawberry yields than the nontreated control, whereas there was no yield difference in comparison with $\mathrm{MB}+$ chloropicrin [26]. Recently López-Aranda et al. [16] suggested that the response with both treatment cited aboved (1,3D + chloropicrin, and DMDS + chloropicrin) was caused by successful soilborne fungus and nematode control, improving strawberry growth and development, which resulted in increased plant canopy diameters and higher strawberry early and total yield.

Our results with chloropicrin alone has shown an equal commercial yield than the control MB + chloropicrin, but according to Daugovish et al. [7] not seems to provided a complete protection against M. phaseolina; responsible of the Charcoal rot disease. Although the main soilborne diseases in southern Spain are crown rot (Phytophthora cactorum), verticillium wilt (Verticillium spp.), and black root rot (Fusarium spp., Rhizoctonia spp., Pythium spp., and Cylindrocarpon spp.) [27], M. phaseolina is emerging as an important disease in strawberry production fields in Florida [20], Israel [30], California [12] and Spain [3], and there are evidences in France, India and Egypt [19].

Although non-chemical treatments such as steam, soil solarization, soilless cultivation, or biofumigation are still considered risky and/or not economically viable to be used alone as alternatives to MB [1], in this work promising results are obtained with the biosolarization with fresh chicken manure. This kind of treatments will be of great interest particularly in Mediterranean European countries, where there are serious problems for chemical fumigant applications due to the implementation of the Directive 91/414/EEC. Currently, of the treatments usually employed at Huelva for strawberry production, dazomet is the unique molecule included in the Annex 1 [31]. 1,3-dichloropropene is not included in the Annex I of this Directive EEC, and its use is limited for National Emergence Uses only (periods of 120 days), and chloropicrin can be used until June 30th 2013. It is discussing the inclusion (or not) in Annex I of chloropicrin (very possible phase-out of chloropicrin in EU).

\section{Conclusions}

The fumigant treatments DMDS + chloropicrin, 1,3D + chloropicrin and chloropicrin alone have shown very good results as $\mathrm{MB}+$ chloropicrin chemical alternatives in this series of trials for strawberry in Huelva (Spain). Also, the new non-chemical treatment with biosolarization with fresh chicken manure has shown interesting preliminary results and it seems to be a very good practice to continue developing this non chemical alternative at a bigger scale in the coastal area of Huelva.

\section{Acknowledgments}

The authors gratefully acknowledge the INIA Project AT06-006-C7-1, INIA/IFAPA Agreement CC09-074 and FEDER (EU) funds for their support.

\section{References}

[1] H.A. Ajwa, S. Klose, S.D. Nelson, A. Minuto, M.L. Gullino, F. Lamberti and J.M. López-Aranda, Alternatives to methyl bromide in strawberry production in the United States of America and the Mediterranean region, Phytopathol Mediterr 42 (2003), $220-244$.

[2] D.L. Albritton, P.J. Aucamp, G. Megie and R.T. Watson, Scientific assessment of ozone depletion. Global ozone research and monitoring project. Rpt. no. 44, World Meteorology Org., Geneva, Switzerland, 1998, 328 pp.

[3] M. Avilés, S. Castillo, J. Bascón, T. Zea-Bonilla, P.M. Martín-Sánchez and R.M. Pérez-Jiménez, First report of Macrophomina phaseolina causing crown and root rot of strawberry in Spain, Plant Pathology 57 (2008), 382. 
[4] K.R. Barker, Nematode extraction and bioassays. In: Barker, Carter and Sasser (Eds.), An Advanced Treatise on Meloidogyne Vol II. Methodology (1985), 19-35.

[5] A. Cal de, A. Martínez-Treceño, J.M. López-Aranda and P. Melgarejo, Chemical alternatives to Methyl Bromide in Spanish strawberry nurseries, Plant Disease 88 (2004), 210-214.

[6] J. Calatrava, Southwestern Spain strawberry growers awareness of the methyl bromide phase out and their willingness to pay for alternatives, Proc Intl Conf Alternatives to Methyl Bromide (2002), 321-325.

[7] O. Daugovish, S. Koike, T. Gordon, H. Ajwa, M. Bolda and D. Legard, Fumigant and strawberry variety evaluations, in: Macrophomina and Fusarium fields, 2009 Proceedings of MBAO Conference (2009), 13-1 to 13-4.

[8] J.M. Duniway, Status of chemical alternatives to methyl bromide for preplant fumigation of soil, Phytopathology 92 (2002), $1337-1343$.

[9] J.S. Gerik, Evaluation of soil fumigants applied by drip irrigation for liatris production, Plant Dis 89 (2005), 883-887.

[10] S.N. Jeffers and S.B. Martin, Comparison of two media selective for Phytophthora and Pythium species, Plant Dis 70 (1986), $1038-1043$.

[11] W.H. Ko and F.K. Hora, A selective medium for the quantitative determination of Rhizoctonia solani in soil, Phytopathology 61 (1971), 707.

[12] S. Koike, T. Gordon, H. Ajwa, O. Daugovish, C. Bolda, M. Bolda, C. County and D. Legard, Fumigant and strawberry variety evaluations, in: Macrophomina and Fusarium fields, Proceedings 2009 MBAO Conference, San Diego, USA, 2009, 13/1 to 13/4.

[13] J.M. López-Aranda, C. Soria, J.J. Medina, L. Miranda, F. Romero, B. Santos de los, F. Montes, J.M. Vega, J.I. Páez, J. Bascón, A. MartínezTreceño, A. Cal de and P. Melgarejo, Resumen de seis años de trabajos. Alternativas al bromuro de metilo en el cultivo de la fresa en España, Phytoma 160 (2004), 16-26.

[14] J.M. López-Aranda, C. Soria, L. Miranda and J.J. Medina-Mínguez, La situación de las alternativas al Bromuro de Metilo en el sector de la fresa en España. Estudio prospectivo para 2005, Agrícola Vergel 277 (2005), 17-25.

[15] J.M. López-Aranda, L. Miranda, F. Romero, B. Santos de los, C. Soria, R. Pérez-Jiménez, T. Zea, M. Talavera, J.M. Vega, J.I. Páez, J. Bascón and J.J. Medina-Mínguez, La retirada del Bromuro de metilo: Nuestros resultados 2005 y 2006 en la búsqueda de alternativas en la fresa de Huelva. La situación actual del problema, Agrícola Vergel 301 (2007), 42-53.

[16] J.M. López-Aranda, L. Miranda, J.J. Medina, C. Soria, B. De Los Santos, F. Romero, R.M. Pérez-Jiménez, M. Talavera, S.A. Fennimore and B.M. Santos, Methyl, bromide alternatives for high-tunnel strawberry production in Southern Spain, HortTechnology 19 (2009), $187-192$.

[17] J.M. López-Aranda, L. Miranda, C. Soria, R.M. Pérez-Jiménez, T. Zea, M. Talavera, F. Romero, B. De Los Santos, J.M. Vega, J.I. Páez, J. Bascón, F.J. Domínguez, P. Palencia and J.J. Medina, Chemical alternatives to Methyl bromide for strawberry in the area of Huelva (Spain): 2002-2007 results, Acta Hort 842 (2009), 957-960.

[18] J. López-Medina, F. Flores, J.J. Medina-Mínguez, L. Miranda and J.M. López-Aranda, Chemical and non-chemical alternatives to methyl bromide fumigation of soil for strawberry production. J Hortic Sci Biotech 78 (2003), 597-604.

[19] J.L. Maas, Compedium of strawberry diseases, $2^{\mathrm{a}}$ ed., APS Press, S. Paul, Minn, 1998.

[20] J. Merteley, T. Seijo and N. Peres, First report of Macrophomina phaseolina causing a crown rot of strawberry in Florida, Plant Dis 89 (2005), 434.

[21] L. Miranda, J.J. Medina-Mínguez, C. Soria, P. Domínguez and J.M. López-Aranda, Alternativas al bromuro de metilo en la fresa de Huelva. Análisis de la situación y perspectivas a la luz de los resultados obtenidos en 2007, Vida Rural 264 (2008), 54-60.

[22] J.W. Noling and J.P. Gilreath, Methyl bromide, progress and problems: Identifying alternatives to methyl bromide vol. II, Citrus Veg Mag, IFAS Publ., Univ. Florida, Gainesville, 2001, 16 pp.

[23] G. Nombela and A. Bello, Modificaciones al método de extracción de nematodos fitoparásitos por centrifugación en azúcar, Boletín de Sanidad Vegetal, Plagas 9 (1983), 183-189.

[24] E.N. Rosskopf, D.O. Chellemi, N. Kokalis-Burelle and G.T. Church, Alternatives to methyl bromide: A Florida perspective, Plant Dis (2005), Prog. 10-1094/PHP-2005-1027-01-RV.

[25] B.M. Santos and J.P. Gilreath, Chemical alternatives to methyl bromide for vegetable crop production in Florida, United States, Perspectives Agr Veterinary Sci Nutr Natural Resources 1 (2006), 1-7.

[26] B.M. Santos, J.P. Gilreath, J.M. López-Aranda, L. Miranda, C. Soria, J.J. Medina and A. Whidden, Performance of methyl bromide alternatives for strawberry production in Florida and Spain, Proc Florida State Hort Soc 119 (2006), 267-268.

[27] B. Santos de los, C. Barrau, C. Blanco, F. Arroyo, M. Porras, J.J. Medina and F. Romero, Relationship between Trichoderma soil populations and strawberry fruit production in previously fumigated soils, HortScience 38 (2003) 1400-1402.

[28] B. Santos de los, C. Barrau, F. Romero, Strawberry Fungal, Diseases, R. In: R. Dris, R. Niskanen and S.M. Jain (Eds.), Crop management and postharvest handling of horticultural products. Science publishers, Inc. Enfield (NH), USA. Plymouth UK, Volume IV, Diseases and Disorders of Fruit and Vegetables (2004), 233-268.

[29] U.S. Environmental Protection Agency, Protection of stratospheric ozone: Incorporation of Montreal protocol adjustment for a 1999 interim reduction in Class I, Group VI controlled substances, Fed Regist 64 (1999), 29240-29245.

[30] A. Zveibil and S. Freeman, First report of crown and root rot in strawberry caused by Macrophomina phaseolina in Israel, Plat Dis 89 (2005), 1014.

[31] M.J. Zanón-Alonso, P. Michitte and I. Gutiérrez, Desinfección de suelos con dazomet: Primer fumigante de suelo autorizao en el Anejo I de la Directiva Europea 91/4114/EEC, Phytoma 232 (2011), 70-74. 